\title{
Chlorophyll-deficient Mutations Induced in Rice by Alkylating Agents and Azide
}

\author{
T. V. V. Seetharami Reddi and J. Suneetha \\ Department of Botany, Andhra University, Waltair 530003 , India
}

Accepted January 23, 1992

Different types of mutagens are used in inducing variability and became useful tools in mutation breeding programmes. While ionizing radiations still remain a force in inducing genetic variability, a number of chemicals have been found to be equally or more effective mutagens. Various methods have been made to determine the most effective and efficient mutagens and treatment for the induction of desirable characters in a cultivated crop. As a result, an extensive array of highly effective mutagens are now available. The relative ease of application of chemical mutagens has made an unprecedented surge of interest in the artificial induction of mutations. The most extensive attempts to alter the spectrum of mutations and to achieve some degree of mutagen specificity in higher plants have been with chlorophyll deficient mutations because of their ease in detection and frequent appearance after mutagenic treatment (Nilan 1967).

Results of a study with rice, aimed at evaluating the chlorophyll mutation frequency, spectrum, efficiency and effectiveness of some alkylating agents (EMS, MMS) and sodium azide are reported in this paper.

\section{Materials and methods}

Five hundred normal seeds of each of the three rice cultivars viz: Jaya, IR8 and IET 6248 with $13 \%$ moisture content, presoaked for $12 \mathrm{hr}$ in distilled water were treated with chemical mutagens, ethyl methane sulphonate (EMS), methyl methane sulphonate (MMS) and sodium azide at $29 \pm 1{ }^{\circ} \mathrm{C}$. The concentrations used for EMS and MMS were 0.25, 0.50, 0.75 and 1.00 per cent by volume. In case of azide $0.001,0.002,0.004$ and 0.008 molar solutions were administered at $\mathrm{pH} 3$. All the mutagenic treatments were carried out for $12 \mathrm{hr}$ with continuous shaking. As a post-treatment care, the seeds were washed in running water for $30 \mathrm{~min}$, allowed to recover in fresh water for $1 \mathrm{hr}$ and sown directly in seed beds along with untreated controls. Forty panicles per dose were collected at random with which raise the $M_{2}$ population. The frequency and spectrum of chlorophyll mutants were scored nine days after germination on the basis of $M_{1}$ panicles and $M_{2}$ seedlings and classified after Gustafsson (1940). The mutagenic efficiency and effectiveness were estimated following the method of Konzak et al. (1965).

\section{Results}

1. $\mathbf{M}_{1}$ panicle progeny basis: The frequency of chlorophyll mutations calculated on the basis of $M_{1}$ panicle progeny are presented in Table 1 . In the cultivars Jaya and IET 6248 EMS treatment inducted the maximum frequency of chlorophyll mutants followed by azide and MMS in the former and MMS and azide in the latter. On the other hand in IR8 MMS induced the highest frequency of chlorophyll deficient mutants followed by EMS and azide. Cent per cent panicles segregated for chlorophyll mutants at $0.008 \mathrm{M}$ azide in Jaya and $0.5 \%$ 
Table 1. Frequency of chlorophyll

\begin{tabular}{|c|c|c|c|c|c|c|c|c|c|}
\hline \multirow{3}{*}{$\begin{array}{c}\text { Mutagen } \\
\text { Dose }\end{array}$} & \multicolumn{6}{|c|}{ Jaya } & \multirow{2}{*}{\multicolumn{3}{|c|}{$\begin{array}{c}\text { IR-8 } \\
M_{1} \text { Panicles }\end{array}$}} \\
\hline & \multicolumn{3}{|c|}{$\mathrm{M}_{1}$ Panicles } & \multicolumn{3}{|c|}{$\mathrm{M}_{2}$ Seedlings } & & & \\
\hline & $\begin{array}{l}\text { Number } \\
\text { studied }\end{array}$ & $\begin{array}{l}\text { Number } \\
\text { segrega- } \\
\text { ting }\end{array}$ & $\%$ & $\begin{array}{l}\text { Number } \\
\text { studied }\end{array}$ & $\begin{array}{l}\text { Number } \\
\text { segrega- } \\
\text { ting }\end{array}$ & $\%$ & $\begin{array}{l}\text { Number } \\
\text { studied }\end{array}$ & $\begin{array}{l}\text { Number } \\
\text { segrega- } \\
\text { ting }\end{array}$ & $\%$ \\
\hline Control & 21 & - & - & 1661 & - & - & 20 & - & - \\
\hline \multicolumn{10}{|l|}{ EMS $(\%)$} \\
\hline 0.25 & 40 & 34 & 85.00 & 3073 & 323 & 10.51 & 30 & 27 & 90.00 \\
\hline 0.50 & 40 & 37 & 92.50 & 3018 & 313 & 10.37 & 31 & 26 & 83.87 \\
\hline 0.75 & 40 & 36 & 90.00 & 2495 & 298 & 11.94 & 30 & 28 & 93.33 \\
\hline 1.00 & 41 & 31 & 75.60 & 1711 & 163 & 9.52 & 29 & 28 & 96.55 \\
\hline \multicolumn{10}{|l|}{$\operatorname{MMS}(\%)$} \\
\hline 0.25 & 40 & 29 & 72.50 & 2182 & 233 & 10.67 & 30 & 28 & 93.33 \\
\hline 0.50 & 40 & 29 & 72.50 & 2505 & 303 & 12.09 & 30 & 30 & 100.00 \\
\hline 0.75 & 40 & 29 & 72.50 & 3043 & 403 & 13.24 & 30 & 27 & 90.00 \\
\hline \multicolumn{10}{|l|}{$\begin{array}{l}\text { Sodium } \\
\text { azide }(\mathrm{M})\end{array}$} \\
\hline 0.001 & 39 & 22 & 56.41 & 2359 & 178 & 7.54 & 32 & 31 & 96.87 \\
\hline 0.002 & 39 & 25 & 64.10 & 2255 & 309 & 13.70 & 30 & 28 & 93.33 \\
\hline 0.004 & 40 & 30 & 75.00 & 1871 & 235 & 12.56 & 30 & 21 & 70.00 \\
\hline 0.008 & 40 & 40 & 100.00 & 1954 & 315 & 16.12 & 32 & 24 & 75.00 \\
\hline
\end{tabular}

No survival at $1 \% \mathrm{MMS}$ in all varieties

Table 2. Frequency of different kinds of

\begin{tabular}{|c|c|c|c|c|c|c|c|}
\hline \multirow[b]{2}{*}{ Treatment } & \multicolumn{5}{|c|}{ Jaya } & \multicolumn{2}{|r|}{ IR- } \\
\hline & Albino & $\begin{array}{l}\text { Mutation } \\
\text { Virescens }\end{array}$ & $\begin{array}{l}\text { Frequenci } \\
\text { Xantha }\end{array}$ & Other Category & Total & Albino & $\begin{array}{l}\text { Mutation } \\
\text { Virescens }\end{array}$ \\
\hline \multicolumn{8}{|l|}{ EMS $(\%)$} \\
\hline 0.25 & - & $\begin{array}{c}10.30 \\
(98.14)\end{array}$ & $\begin{array}{c}0.19 \\
(1.85)\end{array}$ & - & $\begin{array}{c}10.49 \\
(100.0)\end{array}$ & - & $\begin{array}{c}22.80 \\
(97.61)\end{array}$ \\
\hline 0.50 & - & $\begin{array}{c}9.84 \\
(94.88)\end{array}$ & $\begin{array}{c}0.53 \\
(5.11)\end{array}$ & - & $\begin{array}{c}10.37 \\
(100.0)\end{array}$ & - & $\begin{array}{c}18.00 \\
(98.25)\end{array}$ \\
\hline 0.75 & - & $\begin{array}{c}11.38 \\
(95.30)\end{array}$ & $\begin{array}{c}0.56 \\
(4.69)\end{array}$ & - & $\begin{array}{c}11.94 \\
(100.0)\end{array}$ & - & $\begin{array}{c}6.61 \\
(97.89)\end{array}$ \\
\hline 1.00 & - & $\begin{array}{c}9.23 \\
(96.90)\end{array}$ & $\begin{array}{c}0.29 \\
(3.06)\end{array}$ & - & $\begin{array}{c}9.52 \\
(100.0)\end{array}$ & $\begin{array}{c}1.12 \\
(5.79)\end{array}$ & $\begin{array}{c}17.23 \\
(89.09)\end{array}$ \\
\hline \multicolumn{8}{|l|}{ MMS (\%) } \\
\hline 0.25 & $\begin{array}{c}0.96 \\
(9.01)\end{array}$ & $\begin{array}{c}9.16 \\
(85.93)\end{array}$ & $\begin{array}{c}0.54 \\
(5.15)\end{array}$ & - & $\begin{array}{c}10.66 \\
(100.0)\end{array}$ & - & $\begin{array}{c}17.60 \\
(99.06)\end{array}$ \\
\hline 0.50 & $\begin{array}{c}0.3 \\
(0.33)\end{array}$ & $\begin{array}{c}11.10 \\
(92.40)\end{array}$ & $\begin{array}{c}0.87 \\
(7.26)\end{array}$ & - & $\begin{array}{c}12.27 \\
(100.0)\end{array}$ & - & $\begin{array}{c}15.80 \\
(97.74)\end{array}$ \\
\hline 0.75 & - & $\begin{array}{c}12.50 \\
(94.50)\end{array}$ & $\begin{array}{c}0.72 \\
(5.45)\end{array}$ & - & $\begin{array}{c}13.22 \\
(100.0)\end{array}$ & $\begin{array}{c}0.03 \\
(0.22)\end{array}$ & $\begin{array}{l}14.10 \\
(97.55)\end{array}$ \\
\hline \multicolumn{8}{|l|}{$\begin{array}{l}\text { Sodium } \\
\text { azide (M) }\end{array}$} \\
\hline 0.001 & - & $\begin{array}{c}7.29 \\
(96.60)\end{array}$ & $\begin{array}{c}0.25 \\
(3.37)\end{array}$ & - & $\begin{array}{r}7.54 \\
(100.0)\end{array}$ & - & $\begin{array}{c}17.25 \\
(97.73)\end{array}$ \\
\hline 0.002 & $\begin{array}{c}0.75 \\
(5.50)\end{array}$ & $\begin{array}{c}10.46 \\
(76.30)\end{array}$ & $\begin{array}{c}2.48 \\
(18.12)\end{array}$ & - & $\begin{array}{c}13.69 \\
(100.0)\end{array}$ & $\begin{array}{c}0.76 \\
(5.02)\end{array}$ & $\begin{array}{c}13.92 \\
(91.48)\end{array}$ \\
\hline 0.004 & $\begin{array}{c}0.32 \\
(2.55)\end{array}$ & $\begin{array}{c}7.96 \\
(63.40)\end{array}$ & $\begin{array}{c}4.22 \\
(33.60)\end{array}$ & $\begin{array}{c}0.05 \\
(0.42)\end{array}$ & $\begin{array}{c}12.50 \\
(100.0)\end{array}$ & $\begin{array}{c}0.58 \\
(3.96)\end{array}$ & $\begin{array}{c}12.33 \\
(83.92)\end{array}$ \\
\hline 0.008 & $\begin{array}{c}0.20 \\
(1.26)\end{array}$ & $\begin{array}{c}13.50 \\
(83.80)\end{array}$ & $\begin{array}{c}1.99 \\
(12.61)\end{array}$ & $\begin{array}{c}0.40 \\
(2.53)\end{array}$ & $\begin{array}{c}16.09 \\
(100.0)\end{array}$ & $\begin{array}{c}3.81 \\
(30.47)\end{array}$ & $\begin{array}{c}8.09 \\
(65.19)\end{array}$ \\
\hline
\end{tabular}


mutations in rice in $\mathrm{M}_{2}$

\begin{tabular}{|c|c|c|c|c|c|c|c|c|}
\hline \multirow{2}{*}{\multicolumn{3}{|c|}{$\begin{array}{c}\text { IR-8 } \\
\mathrm{M}_{2} \text { Seedlings }\end{array}$}} & \multicolumn{6}{|c|}{ IET 6248} \\
\hline & & & \multicolumn{3}{|c|}{$\mathrm{M}_{1}$ Panicles } & \multicolumn{3}{|c|}{$\mathrm{M}_{2}$ Seedlings } \\
\hline $\begin{array}{l}\text { Number } \\
\text { studied }\end{array}$ & $\begin{array}{l}\text { Number } \\
\text { segrega- } \\
\text { ting }\end{array}$ & $\%$ & $\begin{array}{l}\text { Number } \\
\text { studied }\end{array}$ & $\begin{array}{l}\text { Number } \\
\text { segrega- } \\
\text { ting }\end{array}$ & $\%$ & $\begin{array}{l}\text { Number } \\
\text { studied }\end{array}$ & $\begin{array}{l}\text { Number } \\
\text { segrega- } \\
\text { ting }\end{array}$ & $\%$ \\
\hline 2594 & - & - & 23 & - & - & 1748 & - & - \\
\hline 3221 & 755 & 23.43 & 37 & 28 & 75.67 & 2860 & 120 & 4.19 \\
\hline 2176 & 400 & 18.38 & 39 & 27 & 69.23 & 1840 & 193 & 10.48 \\
\hline 3506 & 237 & 6.75 & 40 & 29 & 72.50 & 2518 & 262 & 10.40 \\
\hline 3034 & 587 & 19.34 & 37 & 26 & 70.27 & 1315 & 125 & 9.50 \\
\hline 3622 & 645 & 17.80 & 36 & 25 & 69.44 & 2451 & 106 & 4.32 \\
\hline 3279 & 531 & 16.19 & 34 & 24 & 70.58 & 1820 & 115 & 6.31 \\
\hline 3104 & 450 & 14.49 & 36 & 17 & 47.22 & 2382 & 57 & 2.39 \\
\hline 3245 & 573 & 17.65 & 37 & 17 & 45.94 & 2088 & 75 & 3.59 \\
\hline 3010 & 457 & 15.18 & 35 & 18 & 51.42 & 2082 & 84 & 4.03 \\
\hline 3089 & 454 & 14.69 & 31 & 14 & 45.16 & 1427 & 61 & 4.27 \\
\hline 2729 & 339 & 12.42 & 39 & 25 & 64.10 & 2689 & 232 & 8.62 \\
\hline
\end{tabular}

chlorophyll mutations in rice varieties

\begin{tabular}{|c|c|c|c|c|c|c|c|}
\hline \multicolumn{3}{|l|}{8} & \multicolumn{4}{|c|}{ IET 6248} & \multirow[b]{2}{*}{ Total } \\
\hline $\begin{array}{c}\text { Frequencies } \\
\text { Xantha }\end{array}$ & Other Category & Total & Albino & $\begin{array}{l}\text { Mutatior } \\
\text { Virescens }\end{array}$ & $\begin{array}{l}\text { C Frequen } \\
\text { Xantha }\end{array}$ & Other Category & \\
\hline $\begin{array}{c}0.52 \\
(2.25)\end{array}$ & $\begin{array}{c}0.03 \\
(0.13)\end{array}$ & $\begin{array}{r}23.35 \\
(100.0)\end{array}$ & - & $\begin{array}{c}4.16 \\
(99.16)\end{array}$ & $\begin{array}{c}0.03 \\
(0.83)\end{array}$ & - & $\begin{array}{r}4.19 \\
(100.0)\end{array}$ \\
\hline $\begin{array}{c}0.32 \\
(1.75)\end{array}$ & - & $\begin{array}{c}18.32 \\
(100.0)\end{array}$ & - & $\begin{array}{c}10.32 \\
(98.44)\end{array}$ & $\begin{array}{c}0.16 \\
(1.55)\end{array}$ & - & $\begin{array}{c}10.48 \\
(100.0)\end{array}$ \\
\hline $\begin{array}{c}0.14 \\
(2.10)\end{array}$ & - & $\begin{array}{r}6.75 \\
(100.0)\end{array}$ & - & $\begin{array}{c}10.20 \\
(98.09)\end{array}$ & $\begin{array}{c}0.19 \\
(1.90)\end{array}$ & - & $\begin{array}{r}10.39 \\
(100.0)\end{array}$ \\
\hline- & - & $\begin{array}{r}18.35 \\
(100.0)\end{array}$ & - & $\begin{array}{r}9.35 \\
(98.4)\end{array}$ & $\begin{array}{c}0.15 \\
(1.60)\end{array}$ & - & $\begin{array}{r}9.50 \\
(100.0)\end{array}$ \\
\hline $\begin{array}{c}0.16 \\
(0.93)\end{array}$ & - & $\begin{array}{r}17.76 \\
(100.0)\end{array}$ & - & $\begin{array}{c}3.99 \\
(92.45)\end{array}$ & $\begin{array}{c}0.32 \\
(7.54)\end{array}$ & - & $\begin{array}{r}4.31 \\
(100.0)\end{array}$ \\
\hline $\begin{array}{c}0.36 \\
(2.25)\end{array}$ & - & $\begin{array}{r}16.16 \\
(100.0)\end{array}$ & - & $\begin{array}{r}6.26 \\
(99.13)\end{array}$ & $\begin{array}{c}0.05 \\
(0.86)\end{array}$ & 一 & $\begin{array}{r}6.31 \\
(100.0)\end{array}$ \\
\hline $\begin{array}{c}0.25 \\
(1.77)\end{array}$ & $\begin{array}{c}0.06 \\
(0.44)\end{array}$ & $\begin{array}{r}14.44 \\
(100.0)\end{array}$ & - & $\begin{array}{c}2.30 \\
(96.49)\end{array}$ & $\begin{array}{c}0.08 \\
(3.50)\end{array}$ & - & $\begin{array}{r}2.38 \\
(100.0)\end{array}$ \\
\hline $\begin{array}{c}0.40 \\
(2.26)\end{array}$ & - & $\begin{array}{r}17.65 \\
(100.0)\end{array}$ & - & $\begin{array}{r}2.92 \\
(81.33)\end{array}$ & $\begin{array}{c}0.67 \\
(18.66)\end{array}$ & - & $\begin{array}{r}3.59 \\
(100.0)\end{array}$ \\
\hline 0.49 & 0.03 & 14.44 & 1.15 & 2.40 & 0.43 & 0.04 & 4.02 \\
\hline$(3.27)$ & $(0.21)$ & $(100.0)$ & $(28.57)$ & $(59.52)$ & $(10.71)$ & $(1.19)$ & $(100.0)$ \\
\hline 1.23 & 0.55 & 14.11 & 0.91 & 3.36 & & & 4.27 \\
\hline$(8.37)$ & $(3.74)$ & $(100.0)$ & $(21.31)$ & $(78.68)$ & - & - & $(100.0)$ \\
\hline 0.47 & 0.03 & 8.59 & 2.45 & 5.65 & 0.37 & 0.14 & 8.61 \\
\hline$(3.83)$ & $(0.29)$ & $(100.0)$ & $(28.44)$ & $(65.51)$ & $(4.31)$ & $(1.72)$ & $(100.0)$ \\
\hline
\end{tabular}


MMS treatment in IR8. Except for azide treatment in Jaya in none of the cultivars dose dependent relationship was observed.

2. $\mathrm{M}_{2}$ seedling basis: The highest and the lowest mutation frequency was obtained in IR8 and IET 6248 treated with $0.25 \%$ EMS $(23.43 \%)$ and $0.001 \mathrm{M}$ azide $(3.59 \%)$ respectively. In Jaya and IET 6248 the frequency of mutants increased with increase in dose in MMS and azide treated populations respectively. On the other hand in IR8 they tend to decrease with increase in dose of azide. The cultivar IR8 appears to be more mutagen sensitive followed by Jaya and IET 6248. Azide induced the maximum frequency of chlorophyll mutants in Jaya followed by MMS and EMS. In the other two cultivars EMS induced the maximum.

3. Mutation frequency and spectrum: The spectrum of chlorophyll mutants induced include albina, viridis, xantha and others of complex phenotypic expression such as alboviridis and striata. Viridis type was more predominant in all the mutagens in all the cultivars under study followed by xantha, albino and other types (Table 2). Albina type was completely absent in EMS treated Jaya and EMS and MMS treated IET 6248. Most of the complex types occurred less frequently and confined mostly to azide treatments.

Table 3. Efficiency and effectiveness of different mutagens in rice varieties

\begin{tabular}{|c|c|c|c|c|c|c|c|c|c|}
\hline \multirow{2}{*}{$\begin{array}{c}\text { Mutagen/ } \\
\text { Dose }\end{array}$} & \multicolumn{3}{|c|}{ Jaya } & \multicolumn{3}{|c|}{ IR-8 } & \multicolumn{3}{|c|}{ IET 6248} \\
\hline & Effectiveness & \multicolumn{2}{|c|}{ Efficiency } & Effectiveness & \multicolumn{2}{|c|}{ Efficiency } & Effectiveness & \multicolumn{2}{|c|}{ Efficiency } \\
\hline \multicolumn{10}{|l|}{ EMS (\%) } \\
\hline 0.25 & 3.50 & 1.00 & 1.00 & 7.81 & 3.71 & 2.31 & 1.39 & $*$ & 0.25 \\
\hline 0.50 & 1.72 & 0.69 & 1.00 & 3.06 & 1.09 & 1.20 & 1.74 & 6.55 & 0.88 \\
\hline 0.75 & 1.32 & 2.59 & 0.69 & 0.75 & 6.75 & 0.55 & 1.15 & 2.66 & 0.75 \\
\hline 1.00 & 0.79 & 0.67 & 0.26 & 1.61 & 7.75 & 1.17 & 0.79 & 1.50 & 0.61 \\
\hline \multicolumn{10}{|l|}{ MMS $(\%)$} \\
\hline 0.25 & 3.55 & 2.80 & 0.64 & 5.93 & 0.32 & 1.21 & 1.44 & $*$ & 0.49 \\
\hline 0.50 & 2.01 & 4.65 & 0.58 & 2.68 & 0.47 & 4.72 & 1.05 & 3.71 & 0.56 \\
\hline 0.75 & 1.47 & 4.56 & 0.56 & 1.60 & 0.33 & 0.99 & 0.26 & 0.13 & 0.26 \\
\hline \multicolumn{10}{|l|}{$\begin{array}{l}\text { Sodium } \\
\text { azide (M) }\end{array}$} \\
\hline 0.001 & 9.66 & 5.8 & 0.40 & 22.62 & 0.48 & 1.54 & 4.60 & 2.76 & 0.25 \\
\hline 0.002 & 8.78 & 0.88 & 0.70 & 9.73 & 0.56 & 0,86 & 2.58 & 0.08 & 0.15 \\
\hline 0.004 & 402 & 2.17 & 0.43 & 4.70 & 0.44 & 1.41 & 1.36 & 0.11 & 0.23 \\
\hline 0.008 & 2.58 & 11.5 & 0.64 & 1.99 & 0.80 & 0.82 & 1.35 & 0.28 & 0.26 \\
\hline
\end{tabular}

* In these treatments, survival was improved upon control.

$\mathbf{M}=$ Chlorophyll mutation frequency in $\mathbf{M}_{2}$ generation on $\mathbf{M}_{2}$ plant basis.

$\mathrm{L}=$ Lethality or survival reduction.

$\mathbf{S}=$ Seed sterility in $\mathrm{M}_{1}$ plants.

4. Mutagenic efficiency and effectiveness: Data on relative effectiveness and efficiency for treated and control population of the cultivars Jaya, IR8 and IET 6248 are presented in Table 3. Effectiveness decreased with increase in dose in both the alkylating agents and azide in all the three varieties of the present study with the exception of EMS in IR8. Obviously lower concentrations were most effective in all the mutagens in all the cultivars when compared to the higher concentrations. Azide treatments were more effective (two to three fold) in all the varieties over the monofunctional alkylating agents. In IR8 and IET 6248 efficiency was more in the alkylating agents treated populations over the azide treated ones when lethality as well as seed sterility was taken into consideration with the exception of MMS in IR8 where it was slightly less when lethality was taken into account. In the cultivar Jaya also alkylating agents 
showed slightly higher efficiency than azide when sterility was taken as the denominator. The reverse trend was observed when lethality was taken into consideration.

\section{Discussion}

The decreased frequency of chlorophyll mutations observed at high doses of mutagens could either be due to the death of the mutated plants leading to their consequent elimination or due to a selection within the plant, i.e., the diplontic selection (Bekendam 1961, Gaul 1961, 1964, Yamaguchi 1962), since two or more primordial cells are involved in the ontogeny of a spike in cereals (Mackay 1954). In such treatments a very high seedling lethality was observed in $M_{1}$ generation and that corroborates the contention of Gaul (1961) that the whole plant may be dying due to extensive damage and only the relatively resistant ones survive.

In the present study viridis mutants occurred at a maximum frequency followed by xantha, albina and other categories. Earlier workers reported the higher frequency of albina mutants (Swaminathan et al. 1970, Nanda and Misra 1975, Bhan and Kaul 1976, Kaul and Basu 1977, Rao and Rao 1983, Reddi and Rao 1988). However, Bhan and Kaul (1976), Afsar Awan et al. (1980), Reddi and Reddi (1984) and Reddi and Rao (1988) reported a higher frequency of viridis than albina in their studies involving physical and chemical mutagens in rice.

Azide treatments showed higher effectiveness than the monofunctional alkylting agents in all the three cultivars. Chlorophyll mutation rate in $\mathbf{M}_{2}$ generation has been customarily used as a test of the effectiveness of a particular mutagen. The drop in chlorophyll mutation frequency at higher doses necessitates judicious use of this test at high doses of the mutagens. The differences in efficiency observed in the present study may be attributed to higher percent of spikelet sterility. Of the two methods of evaluating the potency of mutagens, efficiency has more practical value to the breeder than the other method.

\section{Summary}

The three cultivars of rice were treated with sodium azide and two alkylating agents EMS and MMS with a view to find out the frequency, spectrum, efficiency and effectiveness of chlorophyll mutations in relation to the genotype and the nature of the mutagen. Chlorophyll mutation frequency was enhanced with increasing dose but dropped at very high doses. Among the chlorophyll mutants induced viridis type formed the majority class. Effectiveness decreased with increase in dose with a few exceptions. Efficiency was more in the alkylating agents treated populations.

\section{References}

Afsar Awan, M., Konzak, C. F., Rutger J. N. and Nilan, R. A. 1980. Mutagenic effects of sodium azide in rice. Crop Sci. 20: 663-668.

Bekendam, J. 1961. X-ray induced mutations in rice. In: Effect of Ionizing Radiations on Seeds. IAEA, Vienna, pp. 609-629.

Bhan, A. K. and Kaul, M. L. H. 1976. Frequency and spectrum of chlorophyll-deficient mutations in rice after treatment with radiation and alkylating agents. Mutat. Res. 36: 311-318.

Gaul, H. 1961. Studies on diplontic selection after X-irradiation of barley seeds. In: Effects of Ionizing Radiations on seeds. IAEA, Vienna, pp. 117-138.

- 1964. Mutations in plant breeding. Rad. Bot. 4: 155-232.

Gustafsson, A. 1940. The mutation spectrum of the chlorophyll apparatus. Lund University Arsskrist 36: $1-40$.

Kaul, M. L. H. and Basu, A. K. 1977. Mutagenic effectiveness and efficiency of EMS, DES and gamma rays in rice. Theor. Appl. Genet. 50: 241-246. 
Konzak, C. F., Nilan, R. A., Wagner, J. and Foster, R. J. 1965. Efficient chemical mutagenesis. In: The Use of Induced Mutations in Plant Breeding. FAO/IAEA, Rome, Pergamon Press, pp. 49-70.

Mackay, 1. 1954. The biological action of mustards on dormant seeds of barley and wheat. Acta Agric. Scand. 4: 419 .

Nanda, A. K. and Misra, R. N. 1975. Studies on induced chloroplast mutation in rice. J. Nucl. Agric. Bio. 4: 83-86.

Nilan, R. A. 1967. Nature of induced mutations in higher plants. In: Induced Mutations and Their Utilization. Proc. Symp. Erwin-Baur-Gedachtnisvorlesungen-IV, Gaterstleben, 1966, Akademie-Verlag, Berlin, pp. 5-18.

Rao, G. M. and Rao, V. M. 1983. Mutagenic efficiency, effectiveness and factor of effcetiveness of physical and chemical mutagens in rice. Cytologia 48: 427-436.

Reddi, T. V. V.S. and Rao, D. R. M. 1988. Relative effectiveness and efficiency of single and combintation treatments using gamma rays and sodium azide in inducing chlorophyll mutations in rice. Cytologia 53: $491-498$.

Swaminathan, M. S., Siddiq, E. A., Singh, C. B. and Pai, R. A. 1970. Mutation breeding in rice in India. In: Rice Breeding with Induced Mutations. Vol. II IAEA, Vienna, pp. 25-43.

Yamaguchi, H. 1962. Genetic variation in grain types of rice after irradiation. I. Gamma irradiation. Jap. J. Breed. 12: 93-100. 